\title{
ANALISIS SIKLUS HIDUP PARIWISATA DALAM PENGEMBANGAN \\ PARIWISATA BERKELANJUTAN DI KAWASAN WISATA \\ LEMBAH HARAU, KABUPATEN LIMA PULUH KOTA
}

\author{
Indah Andesta \\ Politeknik Bintan Cakrawala \\ Email: andesta56@gmail.com
}

\begin{abstract}
Lembah Harau is a nature tourism park in Lima Puluh Kota Regency. Lembah Harau area has with strong potential to attract tourist both in natural attraction and manmade attraction. Concept of tourist area life cycle is used to analyze the position of Lembah Harau based on that concept and then to develop sustainable tourism in Lembah Harau. Sarosah Village is a man-made attraction in Lembah Harau. In which it has the role towards man-made and natural attraction in Lembah Harau area are needed to develop the area for sustainable tourism development. There is the strong relationship between Sarosah Village and Lembah Harau itself to bring the Lembah Harau area to rejuvenation level. Based on natural attraction, Lembah Harau area is consolidation to stagnation level. Although, the concept of Sarosah Village is difference with Lembah Harau area's concept as a conservation area. But Sarosah Village gives the positive impact to develop Lembah Harau and Sarasah Village is following the sustainable development tourism concept.
\end{abstract}

Keywords: Development, natural tourist attraction, man-made tourist attraction, tourist area life cycle.

\section{Pendahuluan}

Taman nasional merupakan sebuah tujuan wisatawan dalam atraksi wisata alam, dimana keberadaan dari taman nasional menjadi hal yang penting dalam peningkatan budaya, sosial, lingkungan dan ekonomi. Dalam pengembangan taman nasional sebagai tempat wisata baik atraksi wisata alam dan atraksi wisata buatan memiliki peluang dalam pengembangan wisata di suatu taman nasional. Atraksi wisata buatan dapat terbagi menjadi dua yaitu pelayanan rekreasi di dalam sebuah taman dan di luar taman yang disediakan oleh masyarakat lokal dan swasta (M. 
Puustinen \& Rouet, 2009). Wisata buatan memiliki daya tarik tersendiri sebagai atraksi wisata, dewasa ini wisata buatan dapat meningkatkan kunjungan wisatawan di suatu destinasi wisata (Aprilia, 2015).

Menurut (Sukmaratri \& Damayanti, 2016) bahwa dibutuhkan diversifikasi produk wisata untuk menghindari kejenuhan pada suatu objek wisata, sehingga dapat mengurangi penurunan jumlah wisatawan. Jika dilihat dari atraksi wisata alam adalah hal penting yang perlu dikembangkan pada suatu destinasi wisata alam. Faktor pendorong lainnya yang menyebabkan wisata buatan diminati oleh wisatawan yaitu sebagai alternatif wisata keluarga baik untuk edukasi atau rekreasi. Dimana tantangan dari wisata buatan adalah perlunya inovatif yang efektif dan efisien yang dikelola secara profesional untuk menjaga kestabilan atau meningkatkan kunjungan wisatawan baik dalam waktu saat ini dan masa yang akan datang (Muafi et al., 2018). Dalam perkembangan, atraksi wisata buatan membawa perubahan pada siklus hidup suatu destinasi wisata.

Dimana pada tahun 1979, kawasan wisata lembah harau diperuntukan sebagai hutan wisata dengan luas 298 ha. Kawasan Wisata Lembah Harau merupakan kawasan taman wisata alam, dan mengalami perubahan status menjadi taman wisata dengan luas 27,5 ha, selain itu status Lembah Harau sebagai cagar alam juga berstatus sebagai taman wisata. Wilayah Lembah Harau terdiri dari cagar alam, objek wisata alam, dan Taman wisata alam (Amadia, 2020). Terdapat berbagai objek wisata alam seperti air terjun, tebing, panorama, ngalau dan taman wisata. Selain itu, di kawasan wisata terdapat hewan yang dilindungi terdiri dari monyet ekor panjang, siamang, simpai, harimau Sumatra, beruang, tapir, kambing hutan, landak dan terdapat 19 jenis burung. Tanaman yang dilindungi di kawasan wisata Lembah Harau seperti anggrek. Potensi wisata alam yang dimiliki Kawasan Wisata Lembah Harau memperhatikan aspek keberlanjutan sebagai daerah konservasi yang berstatus sebagai taman wisata. Dimana, kawasan wisata Lembah Harau tidak hanya dapat dirasakan manfaatnya untuk saat sekarang tetapi untuk generasi selanjutnya tetap merasakan Lembah 
Harau sebagai suatu tujuan wisata yang menonjolkan keindahan alam sebagai daya tarik utama.

Kawasan wisata Lembah Harau terus mengalami pengembangan dari segi daya tarik wisata. Daya tarik tersebut tidak terbatas hanya dari segi wisata alam, dimulai dengan tumbuhnya resort-resort dan wisata buatan. Atraksi wisata buatan menyentuh Kawasan Wisata Lembah Harau berupa taman hiburan. Suatu daerah wisata senantiasa mengalami perubahan dari waktu ke waktu, serta tahapan dari siklus hidup pariwisata suatu destinasi tergantung kepada pengelolaan serta pengembangan dimulai dari tahap penemuan hingga penurunan serta peremajaan suatu destinasi wisata. Perpindahan dari satu tahap ke tahap selanjutnya pada suatu destinasi erat kaitannya dengan faktor keberlanjutan dari destinasi tersebut. Wisata berkelanjutan tidak hanya berfokus pada satu aspek atraksi wisata alam, tetapi yang mendasarinya adalah konsep wisata dari Kawasan Wisata Lembah Harau itu sendiri.

Pada penelitian ini, penulis fokus studi terkait dengan atraksi pariwisata di Kawasan Wisata Lembah Harau yang berhubungan dengan keberlanjutan Kawasan Wisata Lembah Harau Berkaitan dengan hal tersebut, sehingga perlu dilakukan analisis mengenai peran atraksi wisata baik alam dan buatan terhadap pengembangan atraksi wisata di Kawasan Wisata Lembah Harau melalui teori yang dipopulerkan oleh Butler pada tahun 1989 yaitu siklus hidup pariwisata (Tourist Area Life (ycle). Teori tersebut dapat digunakan dalam menganalisis siklus hidup Kawasan Wisata Lembah Harau yang merupakan sebuah destinasi wisata alam yang telah ada sejak jaman Belanda dan terus mengalami perubahan. Analisis selanjutnya berkaitan dengan pariwisata berkelanjutan di Kawasan Wisata Lembah Harau. 


\section{Tinjauan Pustaka}

\section{Konsep Pariwisata Berkelanjutan di Destinasi}

Konsep yang dikenal dengan pariwisata berkelanjutan adalah pembangunan pariwisata yang dapat memenuhi kebutuhan saat ini baik kebutuhan wisatawan,masyarakat lokal, sekaligus untuk melindungi peluang kedepannya dalam pengembangan destinasi wisata (WTO, 2004) mengemukakan bahwa pariwisata berkelanjutan tersebut selaras dengan pembangunan pariwisata yang berkelanjutan. Pendekatan awal yang dapat digunakan dalam menganalisis pariwisata berkelanjutan adalah dengan mengidentifikasi pihak-pihak terkait dan dapat memahami fokus perencanaan pariwisata dan pembangunan. Dimana pariwisata berkelanjutan memiliki perhatian khusus pada pengurangan dampak negatif kegiatan wisata alam di sumber daya alam dan budaya.

Suatu destinasi yang menawarkan aspek baik berupa atraksi wisata alam dan buatan perlu memperhatikan keberlangsungan dari destinasi tersebut. Pariwisata berkelanjutan merupakan tantangan utama untuk sebuah destinasi wisata (Jin et al., 2016). Sangat diperlukannya kontrol dari wisata massal untuk mendapatkan kepuasan wisatawan dan industri pariwisata berkelanjutan. Peran dari pemegang kebijakan dan masyarakat sekitar daya tarik wisata untuk dapat menghindari kerusakan yang terjadi akibat eksploitasi yang berlebihan sumber daya alam dan masyarakat lokal sebagai ruan rumah. Diperlukannya daya dukung lingkungan untuk mendukung suatu aktivitas pada tahap tertentu (Hovinen, 2006).

\section{Atraksi Wisata Alam dan Buatan}

Kegiatan rekreasi pada wisata alam memberikan implikasi penting baik pada aspek ekonomi dan lingkungan, rekreasi dan wisata alam mengalami perubahan dan pengembangan (Buckley, 2003). Kegiatan wisata alam yaitu memiliki kekuatan yang erat dengan alam. Kegiatan wisata alam sangat bervariasi, dapat dilihat dari kegiatan yang pasif seperti viewing dan meluking sampai pada kegiatan aktif yaitu white 
water rafting, mountain biking. Bentuk lain dari wisata alam dibagi menjadi konsumtif terdiri dari memancing dan hunting serta tidak konsumtif adalah walking dan birdwatching (Bell et al., 2007).

Kegiatan wisata alam seperti camping dan hiking terus meningkat, berbeda dengan hunting kegiatan wisata alam menurun dari segi minat wisatawan. Kegiatan wisata yang populer yaitu jet skiing dan snowbiling, kayaking, snowboarding, view or photograph fish, snow-mobiling, ice fishing, sledding, view wildlife, backpacking, day hiking, bicycling, horseback riding dan canoeing. Atraksi alam yang perkembanganya lama yaitu motor-boating, primitive camping, sailing, visit historic sites, downhill skiing, snorkelling/scuba, visit beach/waterside, anadromous fishing, caving, small game hunting, migratory bird hunting, picnicking, warm-water fishing, saltwater fishing, dan swimming.

Kegiatan-kegiatan yang dilakukan di luar berkaitan dengan wisata alam memerlukan ukuran kawasan yang dapat menampung wisatawan saat rekreasi. Perlu diperhatikan selain mengenai faktor sosial, visual dari kawasan yang dapat berpengaruh kepada tingkat kunjungan wisatawan, faktor lainnya yaitu perlu peningkatan dalam bidang management strategic dan environmental management (Deng et al., 2003). Suatu area dengan status Taman Nasional menjadi suatu daya tarik untuk menarik minat wisatawan mengunjungi suatu destinasi.

Untuk memenuhi kebutuhan dan kepuasan wisatawan, di suatu destinasi wisata tidak terlepas dari atraksi wisata buatan. Dalam atraksi wisata buatan pelayanan rekreasi didalam sebuah taman dan pelayanan pariwisata di luar taman dimana kedua hal tersebut disediakan oleh masyarakat lokal, pemerintah dan pihak swasta (J. Puustinen et al., n.d.). Faktor pelayanan merupakan hal yang penting saat wisatawan memilih untuk mengunjungi taman, dimana pelayanan rekreasi di dalam taman akan menimbulkan niat wisatawan untuk tinggal dan menikmati atraksi. Wisata buatan merupakan suatu sumber atraksi di destinasi wisata dan menjadi alasan utama wisatawan untuk mengunjungi suatu destinasi wisata. Wisata buatan 
di suatu negara berkembang hendaknya didukung dengan infrastruktur untuk membangun bidang pariwisata untuk mendapatkan keuntungan dari kegiatan pariwisata (Dorcas et al., 2012). Pengembangan suatu atraksi wisata dapat dianalisis dengan menggunakan teori siklus hidup pariwisata.

\section{Siklus Hidup Pariwisata}

Konsep dari siklus hidup pariwisata dikenalkan oleh (Butler, 2006) untuk menjelaskan evaluasi dari kawasan wisata dari waktu ke waktu. Siklus hidup pariwisata, destinasi pariwisata mengalami progress pada 5 tahap: exploration, involvement, development, consolidation, stagnation and post-stagnation. Selama pada tahap post-stagnation, kawasan wisata menghadapi beberapa kemungkinan mulai dari rejuvenation atau decline. Proses siklus hidup pariwisata dapat dilihat pada Gambar 2.

Tabel 1. Tahapan Siklus Hidup Pariwisata

\begin{tabular}{|c|c|}
\hline Tahapan & Deskripsi \\
\hline $\begin{array}{l}\text { Penemuan } \\
\text { (Exploration) }\end{array}$ & $\begin{array}{l}\text { Sebuah destinasi memiliki potensi untuk dikembangkan menjadi } \\
\text { daya tarik wisata dan suatu kawasan dapat dikembangkan menjadi } \\
\text { daya tarik wisata. }\end{array}$ \\
\hline $\begin{array}{l}\text { Pelibatan } \\
\text { (Involvement) }\end{array}$ & $\begin{array}{l}\text { Tersedianya pelayanan jasa oleh masyarakat lokal, dibangunnya } \\
\text { infrastruktur dalam skala terbatas oleh pemerintah lokal sehinga } \\
\text { telah terdapat kunjungan wisatawan pada waktu tertentu. }\end{array}$ \\
\hline $\begin{array}{l}\text { Pengembangan } \\
\text { (Development) }\end{array}$ & $\begin{array}{l}\text { Investor telah masuk dan mengambil peran dalam pengembangan } \\
\text { atraksi wisata, sehingga dituntut perusahaan lokal untuk } \\
\text { memenuhi standar wisatawan global }\end{array}$ \\
\hline $\begin{array}{l}\text { Konsolidasi } \\
\text { (Consolidation) }\end{array}$ & $\begin{array}{l}\text { Kunjungan wisatawan di suatu destinasi wisata menunjukan } \\
\text { peningkatan yang positif. }\end{array}$ \\
\hline $\begin{array}{l}\text { Stagnasi } \\
\text { (Stagnation) }\end{array}$ & $\begin{array}{l}\text { Suatu destinasi wisata mencapai tingkat kunjungan wisatawan } \\
\text { tertinggi sekaligus tidak terhindari beberapa periode kunjungan } \\
\text { wisatawan stagnan. Sulit untuk mendatangkan wisatawan baru } \\
\text { meskipun telah dilakukan promosi intensif sehingga wisatawan } \\
\text { adalah tipe repeater tourist. Pada tahap ini terjadi gangguan pada } \\
\text { daya dukung lingkungan yang berdampak negatif kepada } \\
\text { lingkungan, sosial dan budaya. }\end{array}$ \\
\hline
\end{tabular}




\begin{tabular}{|l|l|}
\hline $\begin{array}{l}\text { Penurunan } \\
\text { (decline) }\end{array}$ & $\begin{array}{l}\text { Pada tahap ini fasilitas pariwisata berubah fungsi, dimana destinasi } \\
\text { hanya ramai dikunjungi pada waktu tertentu. Kemungkinan } \\
\text { destinasi wisata ditinggalkan oleh wisatawan dan memilih } \\
\text { wisatawan lainnya. }\end{array}$ \\
\hline $\begin{array}{l}\text { Peremajaan } \\
\text { (rejuvenation) }\end{array}$ & $\begin{array}{l}\text { Dilakukan pemanfaatan destinasi dengan menyasar pasar baru, } \\
\text { mengembangkan atraksi wisata yang lebih menarik baik itu berupa } \\
\text { atraksi wisata buatan. }\end{array}$ \\
\hline
\end{tabular}

Sumber: (Ly, 2018)

Tahapan siklus hidup pariwisata yang di kemukan oleh Butler, tidak selalu menunjukkan bahwa tahapan selanjutnya lebih baik dari tahapan sebelumnya. Dijelaskan pada artikel oleh (Abdillah et al., 2015) persepsi kualitas hidup masyarakat lokal terhadap perkembangan wisata di Pangandaran dan Palabuhanratu, menyatakan bahwa dari hal skor ditunjukan bahwa Pangandaran lebih tinggi dibandingkan Palabuhanratu. Hal tersebut terlihat bahwa tahap perkembangan lebih baik dibandingkan pada tahap konsolidasi. (I Gusti Bagus Rai Utama, 2012) mengemukakan bahwa teori siklus hidup pariwisata adalah hal penting dalam menganalisis kebijakan, dan dapat mengetahui bahwa suatu kebijakan berlaku atau tidak pada suatu destinasi wisata. (Damanik et al., 2018) melakukan studi dengan mengumpulkan data kunjungan wisatawan dalam rentang waktu 10 tahun dan menganalisis beberapa provinsi di Indonesia melalui teori siklus hidup pariwisata dapat dipengaruhi oleh aspek promosi dan pengembangan struktur terlihat bahwa tahap pengembangan merupakan tahap yang tergolong kuat berkebalikan dengan tahap eksplorasi lemah.Sebuah tradisi kebudayaan Okokan di Bali sebagai atraksi wisata berada pada tahap pertumbuhan (Windutama et al., 2020). Hal tersebut didukung dengan semakin banyaknya wisatawan yang mengenal Okokan tidak hanya sebatas masyarakat Bali.Okokan pada tahap pertumbuhan tidak terlepas dari komodifikasi budaya. Teori siklus hidup pariwisata tidak hanya terbatas pada kajian destinasi, menurut (Narottama \& Moniaga, 2021) pengaplikasian teori tersebut pada tahap konsolidasi dengan adanya hubungan yang positif antara ekspatariat dengan masyarakat. Selanjutnya, ekspatariat memiliki pengaruh yang positif pada 
perkembangan pariwisata di Ubud baik dari segi teknologi, festival, dan kegiatan seni lainnya.

\section{Metode Penelitian}

Metode penelitian ini menggunakan analisis deskriptif kualitatif dengan sampel pada penelitian ini adalah destinasi wisata Lembah Harau yang terletak di Kabupaten Lima Puluh Kota.

Analisis yang digunakan dalam penelitian ini adalah teori Butler mengenai siklus hidup pariwisata. Pada penelitian ini difokuskan pada analisis siklus hidup pariwisata dalam pengembangan pariwisata berkelanjutan di kawasan wisata Lembah Harau. Penelitian mengenai siklus hidup pariwisata objek wisata di Kabupaten Lima Puluh Kota sebelumnya telah dilaksanakan penelitian oleh (Roli et al., 2016).

Metode pengumpulan data dilakukan penulis melalui studi pustaka sebelum penulis melaksanakan wawancara mendalam serta pengamatan langsung di kawasan Lembah Harau. Studi pustaka dilakukan penulis berkaitan dengan teori Butler dan penelitian-penelitian terdahulu yang berkaitan dengan kawasan Lembah Harau. Selanjutnya, pengumpulan data sekunder berasal dari Dinas Pariwisata dan Kebudayaan Kabupaten Lima Puluh Kota, Badan Pusat Statistik Kabupaten Lima Puluh Kota. Sebagai dasar penelitian maka dikumpulkan teori-teori yang berhubungan dengan siklus hidup destinasi wisata melalui variabel yang berpengaruh dalam siklus hidup destinasi kawasan wisata. Kemudian, teori-teori tersebut dirumuskan variabel dalam penelitian. Hingga pada tahap akhir, dilakukan tahap generalisasi hasil, yaitu menarik kesimpulan berdasarkan hasil analisis yang didukung dengan kondisi eksisting dan hasil perumusan kawasan wisata alam berdasarkan teori siklus hidup destinasi pariwisata.

Dalam pengumpulan data primer, penulis melakukan wawancara mendalam kepada pihak-pihak yang terkait seperti manajemen Kampung Sarosah, masyarakat 
di Lembah Harau, bagian pariwisata di Kenagarian Harau serta Dinas Pariwisata dan Kebudayaan Kabupaten Lima Puluh Kota. Hasil wawancara yang diperoleh oleh penulis akan dikombinasikan dengan pengamatan lapangan dalam hasil penelitian ini. Studi pustaka yang dikumpulkan penulis akan dapat dikolaborasikan dengan hasil dari wawancara mendalam serta pengamatan lapangan di kawasan Lembah Harau.

Analisis data merupakan proses mencari dan menyusun data yang diperoleh secara sistematis, dengan mengorganisasikan data ke dalam kategori, menjabarkan ke dalam unit-unit, melakukan sintesa, menyusun ke dalam pola, memilih mana yang penting untuk dipelajari, dan membuat kesimpulan sehingga mudah dipahami oleh diri sendiri maupun orang lain (Sukaryono Feru, 2012).

Analisa data digunakan untuk membantu memberikan pilihan terbaik dari kondisi nyata yang ada di lapangan, serta memberikan pemahaman yang luas akan suatu konsep yang akan dijalankan. Adapun proses analisis data dalam penelitian ini disusun sesuai sasaran penelitian, yang dapat dilihat pada tabel berikut.

Tabel 2. Metode Analisis Penelitian

\begin{tabular}{|c|c|c|c|}
\hline No & Sasaran & Teknik Analisis & Output \\
\hline 1 & $\begin{array}{l}\text { Mengidentifikasi } \\
\text { karakteristik atraksi wisata } \\
\text { buatan di kawasan wisata } \\
\text { Lembah Harau }\end{array}$ & $\begin{array}{l}\text { Analisis } \\
\text { deskriptif } \\
\text { kualitatif }\end{array}$ & $\begin{array}{l}\text { Karakteristik atraksi wisata } \\
\text { buatan kawasan wisata } \\
\text { Lembah Harau }\end{array}$ \\
\hline 2 & $\begin{array}{l}\text { Menganalisis atraksi wisata } \\
\text { alam dan buatan di kawasan } \\
\text { Lembah Harau berdasarkan } \\
\text { teori siklus hidup pariwisata. } \\
\text { Kawasan Lembah Harau } \\
\text { dianalisis berdasarkan peran } \\
\text { dari Kampung Sarosah. }\end{array}$ & $\begin{array}{l}\text { Deskriptif dengan } \\
\text { pendekatan } \\
\text { TALC }\end{array}$ & $\begin{array}{l}\text { Tahap perkembangan } \\
\text { atraksi wisata alam, buatan } \\
\text { di kawasan wisata Lembah } \\
\text { Harau berdasarkan teori } \\
\text { TALC. Tahap } \\
\text { perkembangan wisata } \\
\text { Lembah Harau berdasarkan } \\
\text { peran Kampung Sarosah. }\end{array}$ \\
\hline
\end{tabular}

Sumber: Penulis, 2020 


\section{Hasil dan Pembahasan}

Dalam menganalisis siklus hidup pariwisata pada pengembangan wisata berkelanjutan dilakukan dengan melakukan analisis mengenai Kampung Sarosah sebagai atraksi wisata buatan yang memberikan dampak terhadap pengembangan Kawasan Wisata Lembah Harau melalui tahapan siklus hidup pariwisata.

\section{Kampung Sarosah Sebagai Atraksi Wisata Buatan}

Destinasi Wisata Lembah Harau didominasi oleh objek-objek wisata alam yang terdiri dari beberapa air terjun, tebing-tebing menjulang tinggi dan panorama Lembah

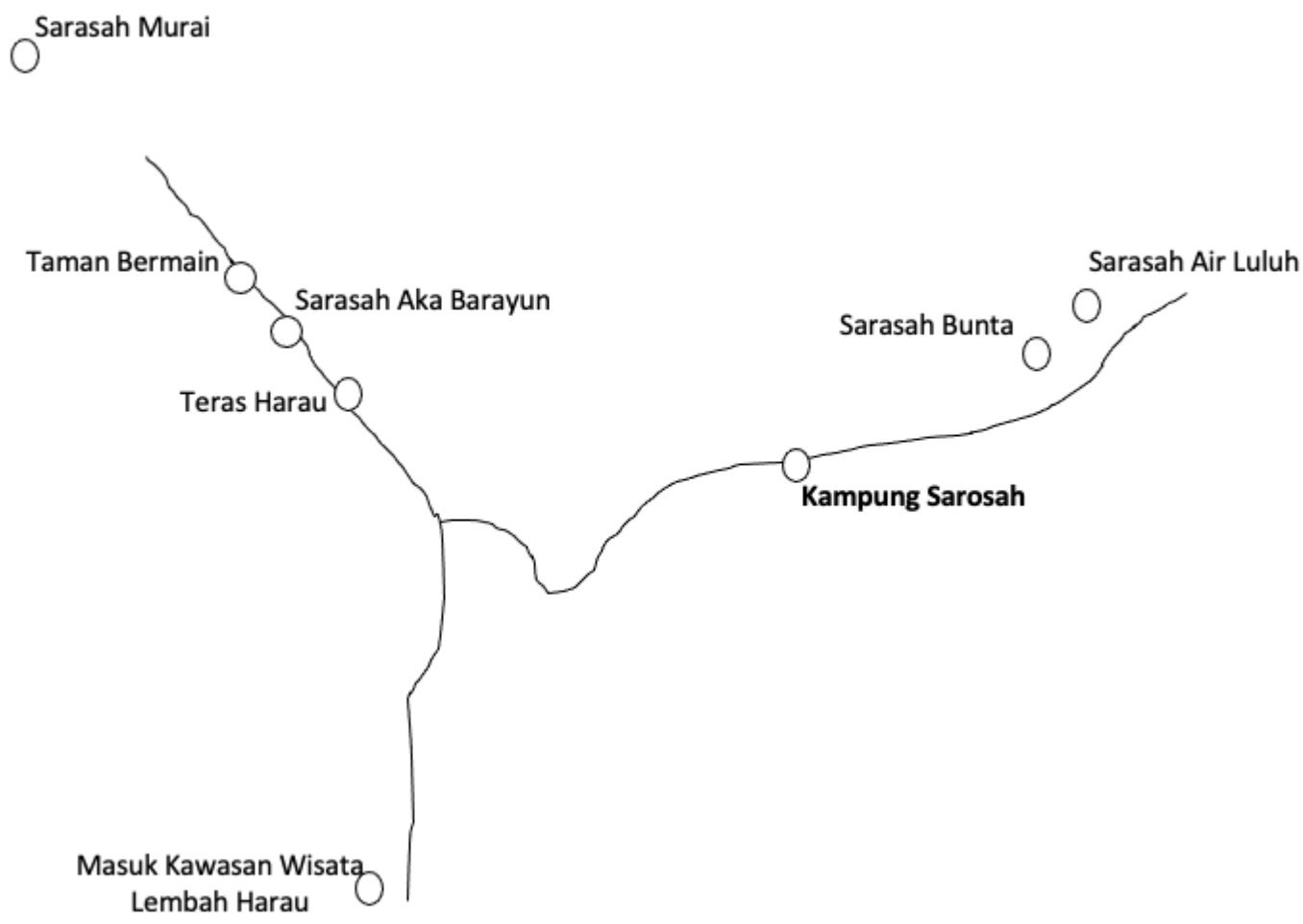

Gambar 1. Denah Lokasi Kampung Sarosah di Kawasan Wisata Lembah Harau

Harau yang hijau menjadi daya tarik tersendiri bagi wisatawan mengunjungi Kawasan Lembah Harau. Pada tahun 2017, Kampung Sarosah dibuka sebagai tempat wisata di Kawasan Lembah Harau menjadi daya tarik baru kunjungan wisatawan di Kawasan Lembah Harau. Keberadaan Kampung Sarosah sebagai daya tarik wisata di Kawasan Lembah Harau tidak melalui perencanaan pengembangan Kampung 
Sarosah sebagai sebuah daya tarik wisata, dengan tingginya antusias dari wisatawan yang mengabadikan foto di pohon mati yang dikenal dengan pohon jomblo berlatarkan panorama Lembah Harau. Hal tersebut merupakan dasar berkembangnya Kampung Sarosah menjadi daya tarik wisata di Kawasan Lembah Harau. Pada 2017, tidak terdapat tiket masuk ke Kampung Sarosah, wisatawan hanya diwajibkan membayar tiket parkir kendaraan. Selanjutnya, atraksi pertama yang dikembangkan di Kampung Sarosah yaitu wisata sampan bekerjasama dengan penduduk sekitar Kawasan Wisata Lembah Harau. Pada pengembangan atraksi wisata tahap awal di Kampung Sarosah, hasil pendapatan dibagi rata antara pemilik Kampung Sarosah dan penduduk sekitar. Kampung Sarosah terus melakukan pengembangan atraksi wisata dapat dilihat pada Gambar 2.

2020

2019

2018

2017

Sepeda gantung

Sampan
Replika Kampung

Jepang

Replika Kampung

Korea

Secret garden

Segway

Ezy roller

Gambar 2. Perkembangan Atraksi Wisata Kampung Sarosah

Sumber: Analisa Penulis (2021) 
Tabel 3. Atraksi Wisata di Kampung Sarosah

\begin{tabular}{|l|l|l|l|}
\hline No & Atraksi Wisata & Biaya (Rp) & Keterangan \\
\hline 1 & $\begin{array}{l}\text { Replika Kampung Jepang, Eropa } \\
\text { dan Korea }\end{array}$ & $30.000,00$ & Per orang \\
\hline 2 & Kampung Sarosah & $5.000,00$ & Per orang \\
\hline 3 & Sepeda Gantung & $25.000,00$ & Per orang \\
\hline 4 & Sampan & $20.000,00$ & Per sampan \\
\hline 5 & Sepeda Air Kecil & $30.000,00$ & Per orang \\
\hline 6 & Sepeda Air Besar & $40.000,00$ & Per orang \\
\hline 7 & Mini Shakeway & $30.000,00$ & Perputaran \\
\hline 8 & Easy Roller & $20.000,00$ & Perputaran \\
\hline 9 & Secret Garden (Taman Anggrek) & $10.000,00$ & $\begin{array}{l}\text { Per orang termasuk welcome } \\
\text { drink }\end{array}$ \\
\hline
\end{tabular}

Sumber: Analisis Penulis (2021)

Berdasarkan tabel 3, pengelola Kampung Sarosah tetap mengadakan single tiket terkait dengan tujuan wisatawan melakukan kegiatan wisata di Kampung Sarosah. Pengelola Kampung Sarosah mengatakan bahwa terdapat tipe wisatawan revisit, yaitu dimana wisatawan memiliki niat untuk mengunjungi kembali suatu destinasi (Kuo, n.d.). Tipe wisatawan revisit dipengaruhi oleh motivasi perjalanan, pengalaman masa lampau perceived constrait dan attitude. Faktor-faktor tersebut mempengaruhi pengelola Kampung Sarosah dalam pembuatan paket atraksi wisata dan single atraksi wisata. Dalam perkembangannya Kampung Sarosah membangun penginapan yang terdiri dari tiga penginapan yaitu penginapan Rumah Koto Gadang, Koto Tingga dan Padang Pinang dengan arsitektur berbentuk rumah gadang Sumatera Barat. Total kamar dari tiga penginapan tersebut yaitu 45 kamar.

Untuk mengatasi tingkat kejenuhan wisatawan berwisata di Kampung Sarosah, manajemen Kampung Sarosah selalu berupaya mengadakan pembaharuan dan perbaikan atraksi wisata di Kampung Sarosah. Pembaharuan tersebut tidak berarti penambahan atraksi wisata dikarenakan pihak manajemen Kampung Sarosah mengutamakan ruang terbuka hijau dan lahan parkir yang luas demi kenyamanan wisatawan. 
Dalam pengembangan atraksi wisata di Kampung Sarosah tidak terlepas peran dari investor. Atraksi wisata replika kampung Korea, Jepang, Eropa, secret garden, dan wahana bermain lainnya. Pada perkembangannya terdapat tiga investor di Kampung Sarosah. Menurut pihak pengelola, banyak tawaran investor yang masuk dalam pengembangan atraksi. Tetapi pihak pengelola Kampung Sarosah harus melakukan review proposal dimana atraksi yang diadakan dapat dipertanggungjawabkan oleh pihak pengelola Kampung Sarosah. Pengembangan Kampung Sarosah masuk pada kategori pengembangan objek wisata yang drastis menunjukan kenaikan. Dalam jangka waktu satu tahun dari di buka nya Kampung Sarosah sebagai objek wisata, telah terdapat investor untuk melakukan pengembangan atraksi wisata di Kampung Sarosah.

Keberadaan Kampung Sarosah sebagai salah satu daya tarik wisata di Destinasi Wisata Lembah Harau mendapatkan kritikan dari berbagai pihak dengan terdapatnya replika kampung Eropa, Korea dan Jepang. Hal tersebut timbul karena konsep yang diangkat Kampung Sarosah dianggap tidak selaras dengan keberadaan Lembah Harau sebagai daerah konservasi. Area Kampung Sarosah seluas 10 ha tidak berada pada zona konservasi. Area yang dijadikan sebagai Kampung Sarosah merupakan rawa dan area pemanfaatan yang dapat di bangun atraksi wisata. Berdasarkan letak dari Kampung Sarosah tidak melanggar peraturan zonasi kawasan konservasi.

Disisi lain dari kritikan yang timbul terhadap Kampung Sarosah, fakta nya Kampung Sarosah memberikan dampak positif terhadap pengembangan Destinasi Wisata Lembah Harau dan ekonomi masyarakat lokal. Dimana para 97\% pedagang di Kampung Sarosah terdiri dari masyarakat lokal. Pihak pengelola dari Kampung Sarosah telah mengadakan perjanjian kerja sama dengan Kenagarian Lubuk Limpato bahwa sebagian besar pedagang dan pekerja lapangan berasal dari masyarakat lokal. Total perbandingan keseluruhan para pekerja di Kampung Sarosah yaitu 70\% dari masyarakat lokal dan 30\% dari luar wilayah Harau. 


\section{Siklus Hidup Kawasan Wisata Lembah Harau}

Berdasarkan analisis penulis bahwa pengembangan atraksi wisata alam di Kawasan Wisata Lembah Harau dapat dikatakan pada tahap pelibatan. Di Kenagarian Harau sendiri air terjun sebagai atraksi wisata alam telah masyarakat lokal menyediakan jasa makanan dan minuman. Pembangunan infrastruktur wisata masih sangat terbatas. Contoh akses menuju Sarasah Murai belum dilakukan perbaikan, tanah dan kerikil. Hal ini berbeda dengan akses taman bermain dan sarasah aka barayun yang dikelola oleh Dinas Pariwisata dan Olahraga Kabupaten Lima Puluh Kota. Air terjun yang terdapat di Kawasan Wisata Lembah Harau mengalami kenaikan kunjungan wisatawan pada waktu-waktu tertentu. Belum terdapat investor yang terlibat dalam pengembangan atraksi wisata alam di Kawasan Wisata Lembah Harau.

Atraksi wisata alam di Kawasan Wisata Lembah Harau mengalami beberapa persoalan untuk menuju pada tahap pengembangan. Hal tersebut berkaitan dengan status kepemilikan tanah di Kawasan Wisata Lembah Harau yang terdiri dari milik BKSDA, masyarakat dan swasta. Pada umumnya area di sekitar air terjun adalah tanah milik masyarakat, hal tersebut menjadi suatu kendala dalam melakukan pengembangan atraksi wisata alam. Selanjutnya, proses yang panjang menjadi salah satu keterlambatan pengembangan wisata di Kenagarian Harau Kawasan Wisata Lembah Harau, yang terdiri dari Ninik Mamak, Alim Ulama, Pemuda, Bamnus dan lainnya, sehingga diskusi yang dilakukan sangat panjang dan masih terdapat ketakutan jika atraksi wisata alam yang berada di sekitar masyarakat di kembangkan berdampak negatif kepada tumbuh kembang anak-anak di Kenagarian tersebut.

Dalam pengembangannya, belum terdapat sinkronisasi antara Dinas Pariwisata, Kebudayaan dan Olahraga Kabupaten Lima Puluh Kota dengan BKSDA. Hal tersebut dikarenakan Kawasan Wisata Lembah Harau merupakan kawasan cagar alam yang telah diturunkan menjadi Taman Wisata Alam. Telah adanya keterbukaan 
dari BKSDA untuk pengembangan wisata di Kawasan Lembah Harau. Dapat dikatakan, atraksi wisata alam di Kawasan Lembah Harau belum optimal dalam melakukan pengembangan wisata, hal tersebut tergambar dari atraksi-atraksi wisata alam yang belum dikembangkan dengan optimal baik dari pemerintah daerah, pihak pribadi dan swasta. Keterlambatan pengembangan atraksi wisata alam di Kawasan Lembah Harau tidak sejalan dengan pengembangan atraksi buatan Kampung Sarosah di Kawasan Lembah Harau. Konsep theme park Eropa, Jepang dan Korea yang kurang pas dengan Kawasan Lembah Harau sebagai cagar alam. Tetapi dampak positif dari Kampung Sarosah berpengaruh kepada siklus hidup Kawasan Lembah Harau. Pada atraksi wisata alam berada pada tahap pelibatan, dan hal tersebut berbeda dengan Kampung Sarosah sebagai atraksi wisata buatan yaitu pada tahap pengembangan. Dalam jangka waktu 3 tahun, telah terdapat tiga investor di Kampung Sarosah, peningkatan jumlah wisatawan naik sebesar 35\% dari tahun sebelumnya.

Tabel 4. Karakteristik Siklus Hidup Atraksi Wisata Lembah Harau

\begin{tabular}{|c|c|c|c|c|c|}
\hline \multirow[t]{3}{*}{ Tahapan } & \multirow[t]{3}{*}{ Karakteristik } & \multicolumn{4}{|c|}{ Hasil Observasi } \\
\hline & & \multicolumn{2}{|c|}{$\begin{array}{l}\text { Atraksi Wisata } \\
\text { Alam }\end{array}$} & \multicolumn{2}{|c|}{$\begin{array}{l}\text { Kampung } \\
\text { Sarosah }\end{array}$} \\
\hline & & Sesuai & Tidak & Sesuai & Tidak \\
\hline \multirow[t]{4}{*}{ Penemuan } & Ditemukan tempat wisata baru & & & & \\
\hline & $\begin{array}{l}\text { Terdapat keindahan alam yang } \\
\text { masih alami dan asli }\end{array}$ & & & & \\
\hline & $\begin{array}{l}\text { Terdapat kunjungan wisatawan } \\
\text { dalam jumlah kecil }\end{array}$ & & & & \\
\hline & $\begin{array}{l}\text { Dapat berinteraksi dengan } \\
\text { penduduk lokal dengan leluasa }\end{array}$ & & & & \\
\hline \multirow[t]{3}{*}{ Keterlibatan } & $\begin{array}{l}\text { Penyediaan layanan jasa untuk } \\
\text { wisatawan oleh masyarakat } \\
\text { lokal }\end{array}$ & & & & \\
\hline & $\begin{array}{l}\text { Sosialisasi atau pemasaran } \\
\text { dalam skala kecil }\end{array}$ & & & & \\
\hline & $\begin{array}{l}\text { Terjadi kunjungan tinggi pada } \\
\text { waktu-waktu tertentu }\end{array}$ & & & & \\
\hline
\end{tabular}


Analisis Siklus Hidup Pariwisata dalam Pengembangan Pariwisata Berkelanjutan...

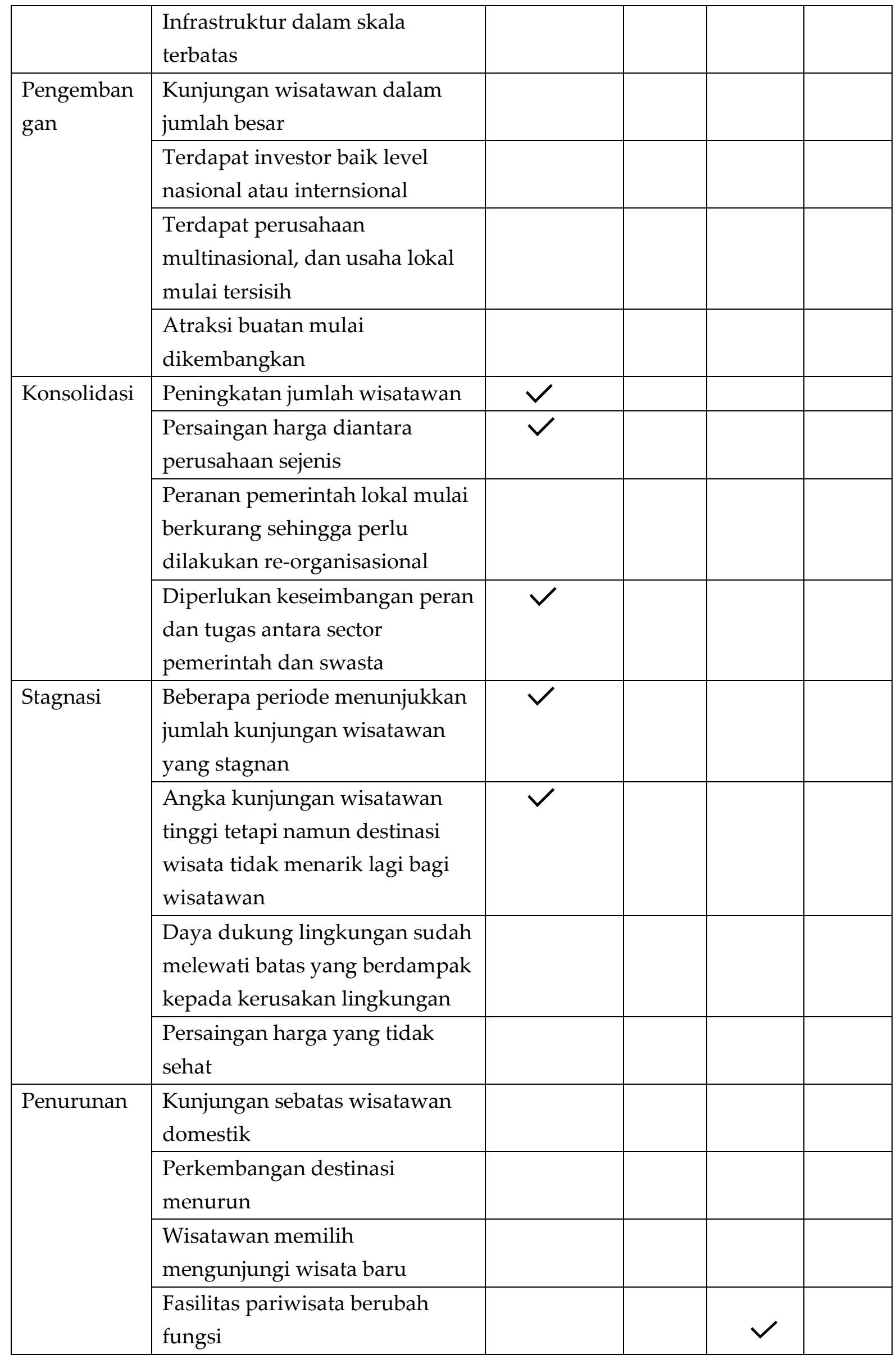




\begin{tabular}{|l|l|l|l|l|l|}
\hline Peremajaan & $\begin{array}{l}\text { Perubahan pada pemanfaatan } \\
\text { destinasi ke yang lebih menarik }\end{array}$ & & & & \\
\cline { 2 - 6 } & Menyasar pasar baru & & & $\checkmark$ & \\
\cline { 2 - 6 } & $\begin{array}{l}\text { Adanya inovasi baru dalam } \\
\text { mengembangkan produk wisata }\end{array}$ & & & $\checkmark$ & \\
\cline { 2 - 6 } & $\begin{array}{l}\text { Membangun atraksi man-made } \\
\text { sebagai usaha peremajaan }\end{array}$ & & & $\checkmark$ & \\
\hline
\end{tabular}

Sumber: Analisis Penulis (2021)

Berdasarkan tabel 4, atraksi wisata alam di Kawasan Lembah Harau berada pada tahap konsolidasi menuju stagnasi, pada tahap ini jumlah kunjungan wisatawan semakin meningkat, tetapi dibutuhkannya hubungan yang jelas antar pemangku kebijakan. Meski tahapan ini telah melawati peran masyarakat yang telah memanfaatkan objek wisata untuk meningkatkan perekonomian mereka. Hal tersebut terlihat pada Sarasah Murai dan Sarasah Bunta dimana terdapat warungwarung dan tempat parkir yang disediakan oleh masyarakat lokal. Infrastruktur masih terbatas, akses menuju Sarasah Murai masih sulit dan tidak terdapat penanda menuju lokasi tersebut. Sehingga hal tersebut berdampak pada kunjungan wisatawan tinggi hanya pada waktu-waktu tertentu pada atraksi wisata alam Kawasan Lembah Harau.

Dilihat dari peran Kampung Sarosah dalam pengembangan Kawasan Lembah Harau yaitu berada pada tahap peremajaan. Kampung Sarosah memberi perubahan pada atraksi wisata buatan baru yang lebih menarik melalui masuknya investor dalam melakukan pengembangan atraksi wisata di Kampung Sarosah. Terdapat inovasi-inovasi dalam melakukan pengembangan Kampung Sarosah, muncul nya atraksi-atraksi wisata buatan baru yang dapat menarik wisatawan, hal tersebut untuk menghindari kejenuhan wisatawan mengunjungi Kampung Sarosah. Dalam menarapkan tersebut pihak pengelola Kampung Sarosah menganalisis terlebih dahulu bahwa atraksi wisata buatan yang dikembangkan akan dapat dipertanggungjawabkan baik untuk investor dan owner dari Kampung Sarosah. 
Kampung Sarosah adalah sebagai perubahan yang terjadi di Kawasan Lembah Harau untuk menarik kunjungan wisatawan sebagai atraksi wisata buatan.

Kampung Sarosah tidak memberikan dampak negatif terhadap alam Lembah Harau. Tetapi, konsep yang ditawarkan yaitu mengusung theme park tidak pas dengan Kawasan Lembah Harau yang merupakan daerah konservasi meskipun saat ini status Lembah Harau telah menjadi taman wisata. Pariwisata berkelanjutan pada tahap ini tidak sebeatas yang dapat merusak lingkungan, tetapi pengembangan wisata Kawasan Wisata Lembah Harau, perlahan merubah image wisatawan ke Lembah Harau yang pada awalnya yang diunggulkan adalah atraksi wisata alam. Kenyataan pada saat ini atraksi wisata buatan yang dikelola oleh pemerintah. Hubungan yang terjalin antara Kampung Sarosah dan Lembah Harau adalah simbiosis mutualisme yaitu hubungan yang terjalin antara Kawasan Lembah Harau dengan Kampung Sarosah. Bagi Kawasan Lembah Harau, kunjungan wisatawan meningkat drastis adalah dampak keberadaan dari Kampung Sarosah. Sedangkan bagi Kampung Sarosah, dapat dikunjungi dengan jumlah wisatawan yang tinggi dipengaruhi oleh keindahan alam dari Lembah Harau. Hal tersebut didukung dengan data kunjungan wisatawan pada gambar 3.

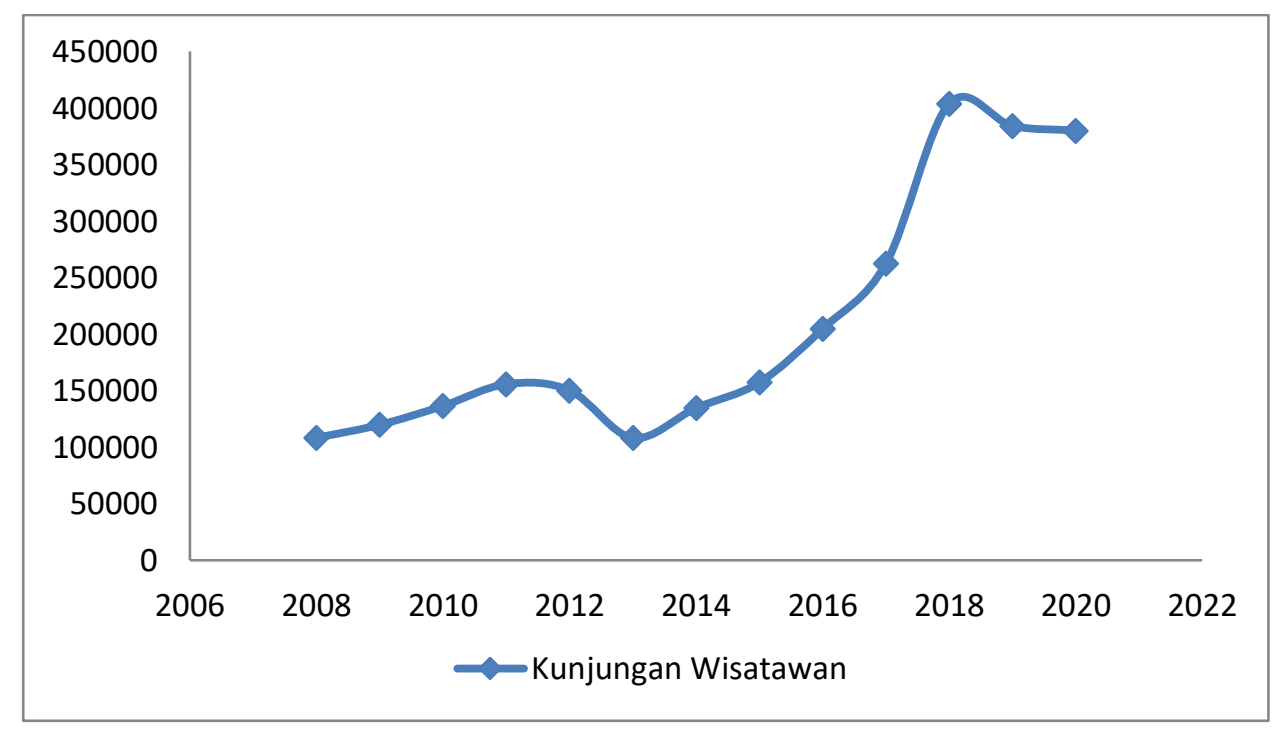

Gambar 3. Kunjungan Wisatawan Kawasan Lembah Harau

Sumber: Dinas Pariwisata dan Olahraga Kabupaten Lima Puluh Kota (2021) 
Berdasarkan gambar kunjungan wisatawan di Kawasan Wisata Lembah Harau, pada tahun 2013, terjadi -39 \% penurunan jumlah wisatawan. Perlahan Kawasan Wisata Lembah Harau mengalami kenaikan dari segi kunjungan jumlah wisatawan. Pada tahun 2018 terjadinya peningkatan sebesar 35\% jumlah kunjungan wisatawan dari tahun sebelumnya. Selanjutnya, peningkatan drastis angka jumlah kunjungan wisatawan dari tahun 2018 sampai dengan tahun 2020. Meningkatnya kunjungan wisatawan di rentan tahun tersebut tidak terlepas dari peran Kampung Sarosah sebagai salah satu atraksi wisata di Kawasan Lembah Harau.

Penelitian mengenai perkembangan objek wisata di Kabupaten Lima Puluh Kota telah dilakukan (Roli et al., 2016) dalam rentan waktu 2006-2016 Kawasan Wisata Lembah Harau berada pada tahap kestabilan (Stagnation). Hal tersebut terlihat bahwa kawasan Lembah Harau akan menghadapi masalah terkait dengan lingkungan dan sosial budaya dimana jumlah wisatawan tertinggi telah dicapai. Berdasarkan pada gambar 2 terlihat bahwa puncak tertinggi kunjungan wisatawan di Kawasan Lembah Harau di tahun 2018. Analisis penulis menarik kesimpulan bahwa Kawasan Lembah Harau berada pada tahap peremajaan. Linear dengan penelitian yang dilakukan (Roli et al., 2016). Kawasan Lembah Harau pada tahap kestabilan (Stagnation), dan dengan peran dari Kampung Sarosah sebagai atraksi wisata buatan di Kawasan Lembah Harau membangkitkan euphoria wisatawan untuk mengunjungi Kawasan Lembah Harau.

\section{Peruntukan Kawasan Wisata Lembah Harau sebagai Konservasi}

Konsep yang dibawa oleh Kampung Sarosah yaitu wisata buatan, jika dilihat dari lokasi tidak berada daerah konservasi dan peruntukan dibangunnya Kampung Sarosah adalah untuk kegiatan pariwisata. Kampung Sarosah memasukkan nuansa baru pada Kawasan Wisata Lembah Harau, sehingga pada pengembangan Kawasan Wisata Lembah Harau peran dari pihak swasta sangat penting dalam meningkatkan kembali minat wisatawan mengunjungi Kawasan Wisata Lembah Harau. Hal tersebut 
sejalan dengan penelitian (Ismawati, 2017) bahwa sebelumnya Kawasan Wisata Lembah Harau di Kelola oleh pihak swasta yaitu PT. Gonjong Limo Sakato di tahun 1998 dan berlanjut pada tahun 2000 Kawasan Wisata Lembah Harau dikelola oleh PT. Trio Dhora Nusantara.

Pentingnya peran dari pihak swasta terlihat pada pengembangan wisata yang dilakukan oleh pihak pengelola Kampung Sarosah. Sementara manajemen dari pengelolaan Kawasan Wisata Lembah Harau masih tarik menarik antara pihak Balai Konservasi Sumber Daya Alam (BKSDA), Dinas Pariwisata dan Olahraga Kabupaten Lima Puluh Kota. Semestinya, BKSD, Dinas Pariwisata dan Olahraga serta masyarakat dapat bekerja sama dalam mengembangkan atraksi wisata alam. Senada dengan (I Gusti Bagus Rai Utama, 2017)bahwa dalam pengembangan pariwisata harus mempertimbangkan pendapat serta pandangan dari para stakeholder yang terkait yang berdampak kepada kepentingan lingkungan dan masyarakat. Tidak dapat dipungkiri bahwa terjadi perdebatan antara pihak konservasionis dan industri.

Berdasarkan observasi penulis bahwa air terjun yang ramai dikunjungi oleh wisatawan yaitu Sarasah Bunta dan Sarasah Air Luluh. Sarasah Akar Berayun dikunjungi oleh wisatawan hanya sebagai tempat pemberhentian sementara dan Sarasah Murai sedang dikembangkan untuk kegiatan camping ground dimana peminat nya masih rendah dikarenakan faktor jalan pedestrian dan lokasi yang jauh dari objek wisata lainnya. Selanjutnya, Kawasan Wisata Lembah Harau kaya akan potensi wisata baik dari segi atraksi wisata alam, budaya baik dari tradisi masyarakat, sejarah, dan legenda dari Kawasan Wisata Lembah Harau. Sangat diperlukan harmonisasi hubungan antara stakeholder yang terkait agar Kawasan Wisata Lembah Harau menjadi destinasi wisata sesuai dengan peruntukannya sebagai area konservasi dan cagar alam. 
Sehubungan dengan peruntukkan dari Kawasan Wisata Lembah Harau sebagai area konservasi dan cagar alam, perhatian lebih mengenai sampah baik di aliran sungai dan di air terjun.

\section{Penutup}

Kawasan Lembah Harau dalam perjalanannya terus mengalami pengembangan, bersangkutan dengan kebijakan yang diambil oleh stakeholder terkait. Penelitian terdahulu menunjukkan bahwa Kawasan Lembah Harau berada pada tahap Stagnation. Selanjutnya, berdasarkan analisis penulis yang membagi siklus hidup atraksi wisata alam dan Kampung Sarosah sebagai atraksi buatan, menunjukan bahwa siklus hidup pariwisata Kawasan Lembah Harau berada pada tahap peremajaan. Dibangunnya atraksi wisata buatan sebagai usaha peremajaan dalam mengembangkan produk wisata ke arah yang lebih menarik. Perlu dikaji kembali kebijakan yang telah ditetapkan oleh stakeholder terkait dengan pengembangan Kawasan Lembah Harau. Stakeholder terkait perlu melakukan diskusi terkait peran Kampung Sarosah yang melakukan pergeseran siklus hidup Kawasan Lembah Harau kepada tahap peremajaan.

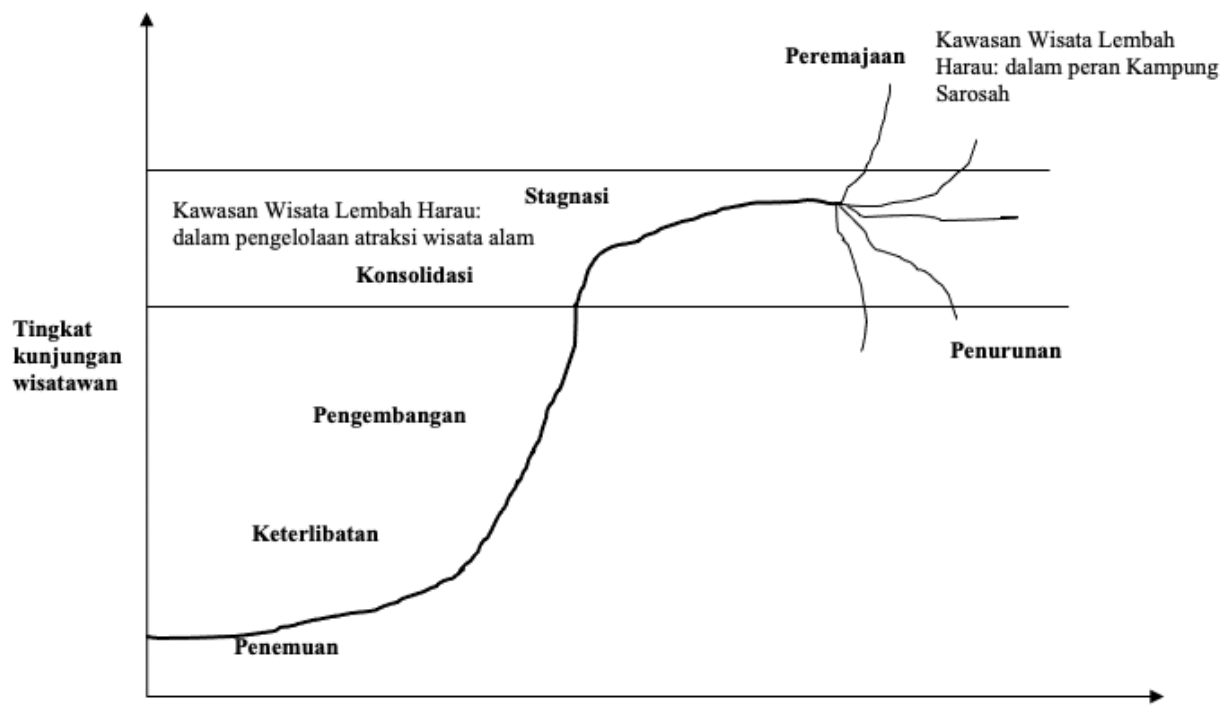

Gambar 4. Tahapan Kawasan Wisata Lembah Harau

Sumber: Analisis Penulis (2021) 
Dimana Kampung Sarosah merupakan atraksi wisata buatan, sedangkan nyawa dari Kawasan Lembah Harau merupakan area cagar alam dan konservasi. Perlu diskusi mendalam terkait dengan konservasi sebagai daya tarik wisata. Seperti yang dikemukan oleh (Suhandi, n.d.) sharing session Ecotourism 25 pada pembahasan Indonesia's Ecotoruism Development mengatakan bahwa "Pariwisata seharusnya bisa menjadi mekanisme pendanaan konservasi, sebab pada dasarnya konservasi berkontribusi besar dan memiliki valuasi yang harus dihitung sebagai daya tarik wisata itu sendiri". Dalam pariwisata berkelanjutan, ekonomi masyarakat tidak mengalami gangguan dengan peran dari Kampung Sarosah. Tetapi wisata konservasi yang seharusnya menjadi daya tarik utama Kawasan Wisata Lembah Harau memudar digantikannya dengan theme park Kampung Sarosah.

\section{Daftar Pustaka}

Abdillah, F., Damanik, J., Fandeli, C., \& Sudarmadji, S. (2015). Perkembangan Destinasi Pariwisata dan Kualitas Hidup Masyarakat Lokal. MIMBAR, Jurnal Sosial dan Pembangunan, 31(2), 339. https://doi.org/10.29313/mimbar.v31i2.1441

Amadia, R. (2020). DESTINATION BRANDING LEMBAH HARAU SEBAGAI KAWASAN EKOWISATA. Jurnal Teknologi Dan Sistem Informasi Bisnis, 2(1), 1021. https://doi.org/10.47233/jteksis.v2i1.83

Aprilia, F., Kumadji, S., \& Kusumawati, A. (n.d.). PENGARUH WORD OF MOUTH TERHADAP MINAT BERKUNJUNG SERTA DAMPAKNYA PADA KEPUTUSAN BERKUNJUNG. 6.

Bell, S., Tyrväinen, L., Sievänen, T., Pröbstl, U., \& Simpson, M. (2007). Outdoor Recreation and Nature Tourism: A European Perspective. Living Reviews in Landscape Research, 1. https://doi.org/10.12942/1rlr-2007-2

Butler, R. (Ed.). (2006). The tourism area life cycle. Channel View Publications.

Damanik, J., Wijayanti, A., \& Nugraha, A. (2018). PERKEMBANGAN SIKLUS HIDUP DESTINASI PARIWISATA DI INDONESIA Analisis Berdasarkan Data Makro Badan Pusat Statistik, 2002- 2012. Jurnal Nasional Pariwisata, 10(1), 1. https://doi.org/10.22146/jnp.59470

Dávid, L. (n.d.). Tourism ecology: Towards the responsible, sustainable tourism future. 9.

Deng, J., Qiang, S., Walker, G. J., \& Zhang, Y. (2003). Assessment on and Perception of Visitors' Environmental Impacts of Nature Tourism: A Case Study of 
Zhangjiajie National Forest Park, China. Journal of Sustainable Tourism, 11(6), 529-548. https://doi.org/10.1080/09669580308667219

Dorcas, M. E., Willson, J. D., Reed, R. N., Snow, R. W., Rochford, M. R., Miller, M. A., Meshaka, W. E., Andreadis, P. T., Mazzotti, F. J., Romagosa, C. M., \& Hart, K. M. (2012). Severe mammal declines coincide with proliferation of invasive Burmese pythons in Everglades National Park. Proceedings of the National Academy of Sciences, 109(7), 2418-2422. https://doi.org/10.1073/pnas.1115226109

Hovinen, G. R. (2006). 5. Lancaster County, the TALC, and the Search for Sustainable Tourism. In R. Butler (Ed.), The Tourism Area Life Cycle, Vol. 1 (pp. 73-90). Multilingual Matters. https://doi.org/10.21832/9781845410278-012

I Gusti Bagus Rai Utama. (2012). ANALISIS SIKLUS HIDUP DESTINASI PARIWISATA BALI: KAJIAN EKONOMI PARIWISATA TERHADAP DESTINAS.

https://www.researchgate.net/publication/270683870_ANALISIS_SIKLUS_HI DUP_DESTINASI_PARIWISATA_BALI_KAJIAN_EKONOMI_PARIWISATA _TERHADAP_DESTINASI

I Gusti Bagus Rai Utama. (2017). Pemasaran pariwisata. In Pemasaran pariwisata (1st ed., Vol. 1, p. 346). Andi Yogyakarta.

Ismawati, I. (2017). STRATEGI PENGEMBANGAN TAMAN WISATA LEMBAH HARAU BERBASIS KEARIFAN LOKAL: TUNGKU TIGO SAJARANGAN. Agriekonomika, 6(2), 151. https://doi.org/10.21107/agriekonomika.v6i2.1830

Jin, Q., Hu, H., \& Kavan, P. (2016). Factors Influencing Perceived Crowding of Tourists and Sustainable Tourism Destination Management. 17.

Kuo, C.-T. (n.d.). Tourist satisfaction and intention to revisit Sun Moon Lake. 6.

Ly, M. B. (2018). An application of Butler's (1980) Tourist Area Life Cycle to Saly (Senegal). 01, 11.

Muafi, M., Wijaya, T., Diharto, A. K., \& Panuntun, B. (2018). Innovation Strategy Role in Tourists Visit Improvement. Context of Man-Made Tourism in Indonesia. Journal of Environmental Management and Tourism, 9(2), 304. https://doi.org/10.14505//jemt.v9.2(26).11

Narottama, N., \& Moniaga, N. E. P. (2021). PERKEMBANGAN DAN INTERAKSI MODAL EKSPATRIAT BERBASIS TOURISM AREA LIFE CYCLE DI UBUD. 7, 33.

Puustinen, J., Pouta, E., Neuvonen, M., \& Sievanen, T. (n.d.). Visits to national parks and the provision of natural and man-made recreation and tourism resources. 15 .

Puustinen, M., \& Rouet, J.-F. (2009). Learning with new technologies: Help seeking and information searching revisited. Computers $\mathcal{E}$ Education, 53(4), 1014-1019. https://doi.org/10.1016/j.compedu.2008.07.002 
Roli, M., Aziz, A., \& Syahar, F. (2016). PERKEMBANGAN OBJEK WISATA DI KABUPATEN LIMA PULUH KOTA. JURNAL GEOGRAFI, 5(2), 143. https://doi.org/10.24036/geografi/vol5-iss2/25

Suhandi. (n.d.). Indonesia's Ecotoruism Development [Persentation]. Ecotourism 25.

Sukaryono Feru. (2012). Pengembangan kawasan wisata budaya kabupaten sumenep [Persentation]. https://docplayer.info/41799484-Pengembangan-kawasanwisata-budaya-kabupaten-sumenep.html

Sukmaratri, M., \& Damayanti, M. (2016). Diversifikasi Produk Wisata Sebagai Strategi Pengembangan Daya Saing Wisata Kota Batu. JURNAL PEMBANGUNAN WILAYAH \& KOTA, 12(3), 325. https://doi.org/10.14710/pwk.v12i3.12907

Windutama, W., Sunarta, I. N., \& Wijaya, N. (2020). Komodifikasi Dalam Pengembangan Tradisi Okokan Sebagai Atraksi Wisata di Desa Kediri, Tabanan. Jurnal Master Pariwisata (JUMPA), 452. https://doi.org/10.24843/JUMPA.2020.v06.i02.p10

WTO. (2004). Indicators of Sustainable Development for Tourism Destinations A Guidebook. World Tourism Organization.

\section{Profil Penulis}

Indah Andesta adalah seorang dosen di Politeknik Bintan Cakrawala. Menyelesaikan pendidikan strata satu di Universitas Gadjah Mada dengan mengambil jurusan pariwisata. Pendidikan strata dua dengan jurusan Leisure Tourism and Environment di Wageningen Univesity, Belanda dengan fokus studi di Tourism Development. Dalam dunia pariwisata, penulis fokus dan minat penelitian pada bidang ekowisata, ekonomi pariwisata, marine, perempuan dan yang berkaitan dengan kebiasaan wisatawan. 